The FIFA World Cup 2002: The effects of terrorism on sport tourists

Associate Professor Kristine Toohey, School of Leisure, Sport and Tourism, University of Technology, Sydney

Phone: 61295145102

Fax: 61295145195

Email: Kristine.toohey@uts.edu.au,

Associate Professor Tracy Taylor, School of Leisure, Sport and Tourism,

University of Technology, Sydney

Phone: 61295145112

Fax: 61295145195

Email: tracy.taylor@uts.edu.au

Professor Choong-Ki Lee, College of Hotel and Tourism,

Kyunghee University, Korea

Phone : 8229619430

Fax : 8229642537

Email: cklee@khu.ac.kr 


\section{The FIFA World Cup 2002: The effects of terrorism on sport tourists}

Keywords: terrorism, sport tourism, football, spectator

Abstract

This paper discusses the relationship between sport and tourism in reference to a specific hallmark event, the Fédération Internationale de Football Association (FIFA) 2002 Football World Cup. In particular, it investigates the terrorism related issues that affected the event and the possible implications for future mega sporting events in Australia. It seeks to contribute to understanding spectator experiences of this event by understanding perceptions of safety and responses to security measures. A questionnaire survey of a convenience based sample of World Cup spectators in the Republic of Korea was undertaken to determine: the extent to which the terrorist attacks on the United States of America on 11 September, 2001 changed these sport tourists' motivations to attend the event; how safe they felt in Korea during the World Cup; and how risk management measures taken by the event organisers impacted on the tourists' level of enjoyment. The findings are discussed in the context of sport event management, concluding with consequences for the future organisation of sports events. While this study focussed on the impact of an act of terrorism, it is suggested that the implications for other critical incidences with global ramifications, such as the recent war in Iraq and the outbreak of Severe Acute Respiratory Syndrome (SARS) need to be taken into account when planning mega sporting events. 


\section{Introduction}

The forces of globalisation have both positively and adversely affected many facets of postmodern culture, including both the sport and tourist industries. Not only has the scope and reach of these two industries been changed, but the relationship between them has been strengthened. During the past three decades there has been a marked transformation in the sport industry's relationship to tourism, particularly via the growth of sport tourism. This confluence represents multiple and overlapping intersections at local, national, regional and global levels and highlights sport as a touristic activity (Hinch \& Higham, 2001).

Sport tourism encompasses a range of activities. Hall (1992) identified three domains of sport tourism: hallmark events; health and fitness; and outdoor recreation. It is the domain of hallmark events which has provided much of the impetus for largescale sport tourism. This paper discusses the relationship between sport and tourism; in reference to a specific hallmark event, the Fédération Internationale de Football Association (FIFA) 2002 Football World Cup. Rather than focussing on the impact of the event on the host countries of the Republic of Korea (South Korea) and Japan, it examines the perceived impacts of the external threats of terrorism on the levels of enjoyment and satisfaction of spectators in Korea. In particular, it discusses the global effects of acts of terrorism on sport tourism.

Primary research was undertaken to determine to what extent the terrorist attack on the twin towers of the World Trade Centre in New York and the Pentagon in 
Washington, on 11 September, 2001 (known colloquially as 911) changed sport tourists' motivations to attend the event, how safe the tourists felt in Korea during the World Cup, and how risk management measures taken by the event organisers impacted on the tourists' level of enjoyment during games. This particular group of sport tourists was investigated because 'individuals who actually attend a World Cup event are a very specialized travel group and may provide considerable insight about travel motivations’ (Wicks, 2002: 129). In terms of background to the study the following key elements are outlined: sport tourism; terrorism; provide examples of the effects of terrorism on sport; and demonstrate how this relates to Australia's growing sporting mega-event industry. Information regarding the 2002 World Cup is presented to provide the specific context for the study.

The data was gathered through a questionnaire survey of a convenience based sample of World Cup spectators in the Republic of Korea. The findings are discussed in a framework of sport event management, concluding with suggestions made for the future organization of such events, especially in an Australian context. While this study focussed on the impact of an act of terrorism, the need for risk management measures to deal with such major episodes would be similar for other critical incidences with global ramifications, such as the recent war in Iraq and Severe Acute Respiratory Syndrome (SARS).

\section{Relevance to Australia}

Australia is a Western liberal democracy with historical ties, and cultural and political affinities to North America and Europe, especially Great Britain. Being 
geographically removed from these two major influencers, it is a country that, in the past, has suffered from a tyranny of distance. However, the effects of this isolation have been diminishing, concurrent to the development of globalisation. While it is located in the Asia-Pacific region, it has only recently begun a policy of active engagement with Asia. One obvious industry that has been transformed through this process is travel, with subsequent growth effects on Australian inbound and outbound journeys. Similarly, global political issues have impacted the nation more immediately, not only because of advances in telecommunications technology, but also because of Australia's increasing involvement in global affairs (Australian Department of Foreign Affairs and Trade, 2003).

Thus, the issue of terrorism is currently in the minds of many Australians and is still regularly capturing headlines in the Australian media, almost two years after 911. The plane hijackings and twin towers attacks were on the other side of the globe, yet it is estimated that 15 Australian nationals died as a result. More recently, three bomb blasts in Bali killed a further 88 Australians and injured over 100 more. According to The Australian Department of Foreign Affairs and Trade (DFAT), (2003:3): 'the terrorist attacks of 11 September 2001 in the United States and 12 October 2002 in Bali have been defining events. They have changed Australia's security environment in significant ways. They starkly demonstrated that threats to Australia's security can be global as well as regional'.

Many of the Bali victims were sports tourists; football teams and their supporters on their post-season trips to the popular Indonesian tourist destination. These tourists were drinking and dancing in the Sari Club and Paddy’s Bar, the sites 
of the first two bombs; nightspots well known and popular with Australians on holiday in the town of Kuta. Subsequently, it has been revealed that the timing of the blast was designed to specifically target these sports tourists (Miller, 2003). The group accused of the bombings is Jamaah Islamiyah, an organization with supposed links to al-Qaeda, the alleged perpetrators of the 9/11 attacks.

These attacks heightened the awareness of many politicians and the public alike to the possibility that a future terrorist attack may occur in Australia. In particular, the threat of terrorism has been linked by the federal government to: the ongoing and divisive issue of immigration; the growing number of Muslim asylum seekers trying to enter the country illegally by boat (people smuggling); and Australia's support of the United States in its 'war against terrorism' (Australian Department of Foreign Affairs and Trade, 2003).

According to DFAT’s White Paper, Advancing the National Interest, 'Australia is committed to the international campaign to eliminate the global threat of terrorism because terrorism threatens Australians at home and overseas. Terrorist groups such as al-Qaeda and Jemaah Islamiyah attack our values' (2003:1). In the lead up to the November 2001 federal elections the Australian Prime Minister, John Howard, had used the fear of terrorism as part of his successful re-election campaign. He announced that there was no way to be certain that terrorists were not among the illegal immigrants trying to enter the country by boat (Atkins, 2001). In a further move, in 2002, once re-elected, the federal government posted an anti-terrorist kit to all Australian households. Included in the pack was information on how to identify a 
terrorist and what to do in case of attack, or suspected attack. A hotline was also set up for citizens to report suspicious individuals or groups. Subsequently, in 2003, legislation has been passed to give the Australian Security Intelligence Organisation (ASIO) greater powers in relation to terrorism.

Also in 2003 the Australian government joined the U.S. - led 'coalition of the willing' and, in this capacity, sent troops into Iraq as part of the alliance's invasion force. This move, itself divisive within the country, has further influenced public perceptions that Australia and Australian tourists are possible targets for a terrorist attack by Islamic extremists.

\section{Sport Tourism}

Sport tourism has had an accelerated growth pattern since the latter part of the twentieth century (Standeven \& DeKnop, 1999). In general terms a sport tourist is someone who visits a destination with the primary reason of participating in or being a spectator of sport. Hinch and Higham’s (2001: 56) definition of sport tourism succulently encapsulates these key aspects: 'sport-based travel away from the home environment for a limited time, where sport is characterised by unique rule sets, competition related to physical prowess, and a playful nature.' This definition of sport fits the characteristics of the matches played in the World Cup tournament.

Gibson (1999) suggested that sport tourism encompasses three macro behaviours: participating (active sport tourism), watching (event sport tourism), and visiting or 
venerating famous sports-related attractions (nostalgia sport tourism). A substantial body of research has focussed on the active sport tourist, examining demographic information, travel patterns, and motivations (Gibson, Attle, \& Yiannakis, 1998; Green \& Chalip, 1998; Nogowa, Yamguchi, \& Hagi, 1996; Tabata, 1992). Event sport tourism includes hallmark events, such as the Olympic Games and the World Cup, and ranges down to small scale, community-based sporting events. At the large-scale end of sport tourism, events such as the Olympic Games have been studied extensively (Warning, Toohey \& Ching, 2001). There are definite links between tourists' motivations for attending mega events and event organisers' motivations in staging them. Roche (2000) proposed that mega events themselves are charismatic spectacles, functional social rituals and products of rational calculation in providing benefits to the event organisers and the region in which they are staged.

Because of the realisation of potential benefits that can result from hosting mega events, the number and scale of sport events has expanded greatly in recent years. Many cities, states and countries have capitalised on the propensity of sport spectators to travel the globe to play and watch sport, and used sports-related events to market destinations. For example, Kim Dae-Jung, the President of South Korea, saw the 2002 FIFA World Cup as 'a chance for [Korea] to make the country prosper diplomatically, economically and culturally, in sectors like tourism and science’ (Korea now, 2001:41, quoted in McCormack, 2002: 39).

The high return on investment makes sport tourism attractive to cities and countries, which can capitalize on sports in two ways; attracting existing events and/or creating their own events (Kelly, 2000). Much of the research on event sport 
tourists has been on assessing their economic impact (Irwin, Wang, \& Sutton, 1996; Faulkner and Raybould, 1995). Gibson (1999) and Nogowa, Yamguchi, and Hagi (1996) commented that there have been relatively few studies in the area of event sport tourism that have focused on the tourist whose main purpose of travel was to attend sports events as spectators. Likewise, Van Leeuwen, Quick \& Daniel (2002) found that very little research has been undertaken on customer satisfaction as it pertains to spectator sport.

While there has been substantial growth in sport tourism, its continued development is closely dependent on overcoming the negative issues impacting globalisation, especially in the high-stakes world of mega events where uncertainties can have dramatic and adverse consequences (Wicks, 2002). As sport is situated within global structures and processes it is therefore subject to the damaging effects of global events, such as 911, which also affected countless countries and other facets of the global society. Economies, political systems, social and community life have all suffered repercussions. Sport tourism around the world has felt the repercussions of this event on several levels that have been highly observable and far ranging in their consequences.

International tours were cancelled or altered, especially in the immediate aftermath of the event, for example the Australian Rugby League team's tour of England in December 2001, the New Zealand cricket tour to Pakistan in October 2001, and golf's Ryder Cup in September, 2001. Events have had to source more security personnel and implement more rigorous anti-terrorism measures, for example 
the Manchester 2002 Commonwealth Games, the 2002 Salt Lake City Winter Olympic Games and the Athens 2004 Summer Olympic Games. Although safety concerns appear to be diminishing it was made known that \$US 225-250 million was spent on security at Salt Lake City, an amount more than double the 1996 Atlanta Olympics (Janofsky, 2002 in Wicks, 2002).

Tourism associated organisations have felt the brunt of the decline in travel and this has had flow-on effects for sport, in that less tourists are incidentally around to attend minor events. However, dedicated sports tourists have reacted differently. One such example relates to the 2002 Salt Lake City Olympic Games.

'Two seemingly contradictory findings emerged from industry reports about the Olympics. First that cancellation for Olympic trips were minimal and second, tickets to many events remained even as late as six weeks prior to the start of the Games. These findings suggest that the highly committed sports fan made his or her plans to attend the event early and were going to attend irrespective of 9/11 and related events. The surprising availability of tickets to most venues may be due to a lack of less committed fans or leisure travellers willing to attend' (Wicks, 2002: 132).

In a recent editorial comment in the Journal of Sport Tourism, John Zauhar (2002) noted that the traditional aspects of sport tourism management, those related to financial loss or risk, property and liability exposures are now being overshadowed by the 'saboteur' element. Zauhar (2002:5) challenged that, 'the "innocence” of the sport 
tourism atmosphere must continue to permeate and not be overcome by the “albatross” of terrorism.' Attending large-scale sport events has been linked to ritualistic behaviour (Real, 1986), and research has found that Olympic Games spectators attended because nothing was as exciting as ‘being there’ (Delphy, 1996). The question is, in this uncertain environment, can major event organisers manage spectator risk whilst still retaining the ritualistic aspect and the excitement that sport spectators have come to expect?

\section{Customer Satisfaction and Expectations}

The growing body of research examining why people attend sporting events and how satisfied they are with the experience has come from a range of disciplines, such as psychology, consumer behaviour, sociology and marketing (Funk \& James, 2001). Triadó, Aparicio and Rimbau (1999) note that many writers have connected customer satisfaction to the notion of 'quality' and propose that three fundamental models have been formulated to account for the role of quality in the construction of satisfaction in sport. These models are: the 'perceived discrepancy model'; the cognitive theory approach; and a 'high implication' paradigm. The first model, developed by Nicosia (1974), sought to explain post-consumption satisfaction in terms of the discrepancy between customer expectations and the perceived quality of service provision they received.

The second model, the cognitive theory approach, asserted that, in addition to the above, satisfaction was also a component of previous consumer expectations. The 
third model, which has the greatest application for this study, has as its basis cognitive dissonance theory and perceived quality, which 'suggests that after a very bad (or good) consumption experience, the psychological costs of adjusting the quality to previous expectancy may exceed the costs of modifying that experience' (Triadó, Aparicio \& Rimbau, 1999:3). Thus, 'to understand customer satisfaction the research focus should be the perceived quality of the main elements of the offer' (Triadó, Aparicio and Rimbau, 1999:3). This aligns with the findings of Hill and Green (2000: 146) who note that 'attention has turned to the role that the facility and its service elements play in fan behaviour and satisfaction'. Similarly, Westerbeek and Shilbury (1999) observed that the facility (stadium) is the primary means by which sport is produced, consumed and delivered to spectators and so facility services are core determinants of satisfying spectator needs. They noted that such 'servicescapes' should be designed to enhance the entertainment element. However, Hill and Green also cautioned that 'it is inadequate to limit the focus to the spectators' experience at the stadium. The experience needs to be understood in terms of the characteristics of fanship that the spectator brings to the event' (Hill \& Green, 2000:159).

A study by Canter, Comber and Uzzel (1989) found 'that the main reasons why football spectators stopped going to the game were the occurrence of violence and the lack of safety at the ground' (quoted in Westeerbeek and Shilbury, 1999:8). They noted there were differences between fanatical supporters and occasional supporters. It was the latter category which was more likely to lose interest in attending if any part of the sportscape was not attractive, for example, their perception of personal safety. The threat of terrorism creates such a scenario. 


\section{Terrorism}

While the term 'terrorism' was first coined during the French Revolution no single definition of terrorism has gained current universal acceptance (United States Department of State, 2001). Most researchers tend to believe that an objective and internationally accepted definition of terrorism can never be fully agreed upon, as any definitive classification of what constitutes a terrorist act is fundamentally motivated by self-interest, open to interpretation, personal perception and exploitation.

Conversely, others say that a definition of terrorism is necessary and a prerequisite to serious efforts to combat it (Ganor, 2001). The absence of agreement on a single, unequivocal meaning has resulted in a number of far ranging consequences; from the fact that that legislating against terrorism is problematic (Whitaker, 2001), to the reality that liberation movements have been pejoratively branded as terrorist movements by those opposing them (Freedman, 2002). Thus the search for what constitutes an acceptable definition of terrorism has vexed the United Nations for over 30 years.

Despite this impasse, it is accepted that terrorism: has always been purposeful; is political in its motives; implies violence or threats thereof; is indiscriminate in its choice of targets; as well as being designed to have consequences beyond its immediate target/s (Freedman, 2002). Thus, there is a strategy behind terrorist actions. The significant intent is that terrorism is politically motivated. 'This is what distinguishes it from... murder or football hooliganism’ (Whitaker, 2001 http://www.guardian.co.uk/elsewhere/journalist/story/0,7792,487098,00.html). 
While terrorism has many aims and forms Selth (1988) has classified it into four broad groupings (although some examples of terrorist acts can involve more than one of these categories): domestic (actions by groups or individuals against others in the same country); state (terror used by authorities to maintain their position within a nation); international (terrorism directed at foreign nationals or governments); and state sponsored (terrorist tactics used by agents of the state, or independent groups to pursue foreign policy aims.

\section{Sport and terrorism}

To date, the study of sport violence has focused on either fan or spectator behaviour. Little work has been carried out on 'actual or threatened acts of violence that may be associated with sporting practices and cultures, but not directly prompted by action on the playing field', such as terrorism (Atkinson and Young, 2000: 54). Despite the fact that sport has not been immune from terrorist activities, 'specialist literature on the relationship between sport and terrorism is rare' (Wedermeyer, 1999:218).

According to Atkinson and Young (2000: 54):

While sports may seemingly share few conceptual links with acts of terrorism... we cannot ignore how sports events may become targets of terrorism... or the contexts of terrorism.... For many reasons, individual terrorists or terrorist organizations might find suitable targets in athletes participating in games, spectators attending the events, or selected corporate sponsors of sports contests.' 
Thus, understandably, the more prestigious the sporting event, the greater the likelihood that terrorism will become an issue. Therefore, the Olympic Games and other mega sporting events, such as the football World Cup, have historically been considered to be prime targets, especially since the late 1960s, when technological advances to the media, through the use of satellites, enabled these events to be broadcast worldwide. This allowed protestors a global real-time audience to publicise their message. As the terrorism expert Brian Jenkins explained in 1974, 'terrorism is theatre’ (Council on Foreign Relations, 2003).

The most notorious example of terrorism in sport occurred in 1972 at the Munich Olympic Games, when members of the Palestinian group, 'Black September' infiltrated the Olympic Village and stormed the Israeli team quarters, killing a Israeli wrestling coach and taking 10 other Israeli athletes and officials hostage. A disastrous rescue was attempted in which all of the Israelis, a German policeman and a number of the terrorists died. As a result of the deaths, four nations (Egypt, Israel, Algeria and the Philippines) withdrew from the Games, as well as individuals from the Dutch and Norwegian teams. The Israeli Government called for the cancellation of the Games, however the IOC decided that 'the Games must go on’ (Brundage, 1972 in Toohey \& Veal, 2000). Since this time security at the Games has become a priority of the organisers. Nevertheless, despite all precautions, terrorism at the Games has not been totally eliminated. 
Security for Olympic athletes and officials has been greatly improved since Munich. However, at the 1996 Atlanta Games, a new form of Olympic terrorism appeared, this time in the form of a bomb blast aimed to kill and/or injure spectators. A bomb, hidden in a knapsack, exploded early in the morning of Saturday, 27 July in Olympic Centennial Park. One spectator was killed, a journalist covering the event died of a heart attack and over 100 others were injured in the attack (Toohey \& Veal, 2000). Despite extensive investigations the terrorist/s have not been brought to justice.

The last Olympic Summer Games were held in Sydney in 2000. As part of the security planning an Olympic Intelligence Centre was created within the organizing committee. It provided a link to the Australian Security Intelligence Organisation (ASIO) and provided intelligence-based risk management that identified and prioritised all Games-related risks (Toohey, 2001).

Among a range of security principles for the Sydney Games the following measures were undertaken:

- ensuring that Olympic related international entry and accreditation processes were consistent with Australia’s existing policies

- making certain all accredited persons were subjected to appropriate background checking

- restricting sensitive areas to accredited persons

- sanitising all Olympic venues and sites for the presence of explosive devices after 'lockdown'

- imposing targeted screening procedures, using metal detectors and searches of hand-carried items for all spectators entering Olympic venues and sites 
- checking all people and items entering higher risk areas such as the Olympic Village

- imposing strict and consistent controls on the entry of vehicles and commercial materials into all Olympic venues and sites’' (Toohey, 2001) .

While security threats were generally considered to be slight, given Australia's internal and external relationships at the time and the security preparations undertaken, there were still considered to be four potential sources of attack: 'state agents of terror, formalized terrorist groups, loosely affiliated extremists and lone militants' (www.terrorism.com/analysis-olympics.shtml, 2000: 1). Each of these was considered to be a unique type of threat, necessitating a different response.

There were two terrorist related incidents pre Games time. In May 2000, a man whose home was discovered packed with explosives was arrested near the Olympic site and then the following month Australian authorities deported five people linked to extremist groups. Interestingly, in light of subsequent events, Islamic extremists, especially groups associated with Bin Ladin, such as al-Qaeda, were listed as one of the loosely affiliated extremists threats (www.terrorism.com/analysisolympics.shtml, 2000).

While there was no recorded instances of terrorism at the 2002 FIFA World Cup, international football, including previous World Cups have been negatively affected by violence, much of it related to politics. The July 1969 Honduras El 
Salvador War, referred to as the 'Football War', was attributed in part to football. When the two countries met in a World Cup qualifying match, the game triggered a war. Long-standing feuds were played out on the pitch, and violence between fans escalated into a full-scale military clash between the countries (http://www.megastories.com/mitch/map/salvador.htm, 2003). This perhaps the most obvious, but by no means the only example of nationalistic football related hostility. Much of this aggression has links to the processes of globalisation. For example, substantial numbers of male football fans have been sport tourists now for over three decades, partly as a result of the development of package tours and cheap international holidays. These latter tourist initiatives have resulted in travel costs falling and flights becoming more readily available. 'For many (especially) 'working class' young men, it was football that first initiated them into 'foreign' travel' (Taylor, 2002: 27). It is no coincidence that during this period, many football sports tourists have displayed violent behaviour at foreign games.

For example, during the last two World Cup Finals in Europe (Italia '90 and France '98) a number of incidents of fan violence occurred, and similar to the terrorist incidents at the Olympic Games, the scenes were played out on world television. Taylor suggests that a large part of this problem was politically motivated.

'The embarrassment that hooliganism inflicted on the [English] nation as a whole goes back thirty years or more... It became increasingly apparent throughout the 1990s (once English clubs were allowed back into European competition) that the worst fans were with the national team. The Clubs seemed to experience few difficulties travelling away to Europe... but every time the England 
team played abroad in serious competition there was trouble.

'Nationalism' was proving a driving force for disorder; a platform on

which the worst aspects of Englishness were regularly paraded.

(Taylor, 2002:32-33).

The authorities have not been idle in attempting to deal with this problem. The recent 'gentrification' of the game in Great Britain, as it attempts to capture a more upmarket fan base, has increased the incentives to management and governments to face up to and solve the issue. The negative implications for continued violence are far reaching, as the FIFA World Cup is the world's biggest sporting event, with a television audience larger than that of the Olympics (Horne \& Manzenreiter, 2002). Australia has indicated that it is interested in bidding for the 2014 World Cup. Thus, understanding the effects of terrorism on a World Cup will have particular significance within an Australian setting.

\section{The 2002 World Cup}

Amidst debates and discussions about safety and security in the post 9/11 atmosphere many sports events went ahead as scheduled and were considered to be profitable from both sport and tourism perspectives. An example of this was the FIFA 2002 Football World Cup. This mega event, held between 31 May and 30 June, was jointly hosted by the Republic of Korea and Japan. It was the first World Cup awarded to Asia and also the first to have two hosts. 
Despite intense political competition and rivalry during the bidding, organisational and construction phases of the event, the final result was an achievement that both host nations and FIFA considered highly successful. Additionally, both countries’ teams could be considered to have had successful tournaments. The Korean national team became the first-ever Asian country to reach the semi-finals in the history of World Cup. In all, more than 2.7 million spectators visited soccer stadiums in the two host countries for the 64 matches played over the one-month period (2002 FIFA World Cup, 2002). Games were equally divided between the two hosts, with 32 games played in each country.

The soccer legacy to the Asian region, as a result of the successes of the tournament in general and the host countries' teams should provide a strong platform to strengthen the game at both amateur and professional levels. The facilities built, especially those that were multi-purpose in their design, will be able to host numerous sport events in the future and it is hoped that they will also be a major draw-card for domestic sport tourists as both countries invested huge amounts into the construction of these venues. An estimated \$US 4.7 billion was invested in sport facilities at the 20 designated venues (Manzenreiter \& Horne, 2002). The economic and image related benefits from the investment in hosting the event were important to both countries, given their long history of intense hostility. In the case of Korea, it was predicted that 'the economic benefits from the World Cup will serve as platform and springboard for South Korea to shape its image as a global player and shed its insular past' (Wall Street Journal, 2002, 21 June in Republic of Korea, 2002b: 2). The Korean government expressed the hope that 'the football fever that has consumed the country will remain an intrinsic force in Korea and serve as a foundation for building stronger 
ties with neighbours such as China and Japan especially through sports exchanges’ (Republic of Korea, 2002a: 13).

After 9/11 and before the tournament began one of the greatest fears and subsequently one of the areas that required the greatest attention of both the event organisers and the national governments of the two host countries was the threat that terrorism would disrupt the event. 'As the stakes for the host nation or region rise with increased travel flows and hopes for positive carry-over effects, so does the need to accurately plan for such major occurrences' (Wicks, 2002: 126). The likelihood of decreased tourist numbers, the cost of additional security measures and the reaction of the spectators to high levels of security checks were all issues that had to be adequately managed by organisers and governments alike.

\section{Terrorism and the 2002 Football World Cup}

Before the attack on the World Trade Center on September 11, 2001 the security planning for the 2002 World Cup had concentrated on measures to deal with hooligans. According to Taylor (2002:32), for the English, the prospect of fighting on the streets of a former wartime foe (Japan) - was inviting. He noted that 'it is no accident that England's fans are most provoked by opponents who used to be real enemies’. However, despite this vulnerability, after 9/11, terrorism prevention and surveillance became the organisers' primary security concern (Asahi Evening News, 2002. 
Indeed, so involved was the anti-terrorist planning that the Cup’s security measures became the strictest for any sporting event to date. Korean and Japanese security organizations, aided by the United States’ FBI and Britain’s MI5 and MI6, were involved in pre-games anti-terrorist planning. During the event, fighter jets patrolled no-fly zones around the stadiums, while surface-to-air missiles were ready to shoot down suspicious aircraft. Sharpshooters were in place at all venues, and, in addition to the normal security measures, undercover operatives, some trained by the Israeli intelligence agency, Mossad and assisted by Israeli Army specialists, were on the lookout for suicide bombers (Sunday Age, 2002). No major terrorist incidents occurred during the event.

However, while the security needed to be tight and thorough, there were also concerns that overtly stringent security could dampen the mood of the event and lessen spectators’ enjoyment (Asahi Evening News, 2002) These tensions then became a question of balance: how much security needed to be provided without destroying the communal experience that the competition represented? (The Washington Post, 2002).

The threat of terrorism also impacted on the event in a number of other ways, for example, the cost of insuring the event rose dramatically (Horne \& Manzenreiter, 2002). In addition, the predicted number of overseas spectators coming to watch the tournament was reduced, as were the subsequent tourism flow on effects after the World Cup (an expected and anticipated legacy of modern mega events). However, there were also other causes of this downturn. A recession was beginning and travel demand was declining before 9/11. 'Even in the best of circumstances, the role played 
by airlines and aircraft in a tragic incident would have significantly impacted travel patterns particularly for the non-essential or leisure travel market... above all industrial sectors tourism has been impacted the most’ (Wicks, 2002: 129).

Tourist arrivals to South Korea were down by five percent in the month of the event, despite predictions that the World Cup would attract record numbers of visitors to the country. While tourist numbers were less than anticipated before $9 / 11$, the event still attracted a significant number of spectators who were willing to travel. This was not an unexpected turn of affairs. While the early planning for the event was optimistic about the crowds that the World Cup would draw, the advent of 9/11 caused a major reassessment of these early predications. The Korean Ministry of Culture and Tourism lowered the anticipated number of foreign visitors in June 2002, to 460000 from the original target of 640000 . A ministry official noted: 'there, however, still exists a World Cup boom in the tourism industry, although the number of foreign visitors did not rise as much as we originally expected. The market diversification will eventually lead to a steady increase in the number of foreign tourists visiting the country in the near future after the World Cup events' (Online Asia Times, 2002). Korean officials hoped that foreign media's extensive coverage of the World Cup, including the strong performance of the Korean team, the scenes of millions of red-shirt-clad people cheering in streets in an orderly manner, together with other positive images of Korean society and culture, would assist in attracting foreign tourists on a mid- and long-term basis.

Despite a decrease in predicted World Cup tourist numbers, there was still an increase of 12 percent and 10 percent for American visitors during June/July respectively, and 
an increase of 55 percent and 18 percent for European visitors in June/July 2002. Sport tourists who decided to travel to the event, despite the threat of terrorism, were surveyed for this paper to better understand spectator experiences of an event by understanding perceptions of safety and responses to security measures.

\section{Method}

Tourists traveling to or within South Korea to attend the 2002 World Cup were surveyed about their reactions, motivations and feelings about the security and safety measures at the event. The sample was selected from self-identified 2002 FIFA World Cup spectators in South Korea employing a convenience sampling procedure. The survey was administered by research-trained students from the College of Hotel and Tourism at Kyunghee University. Students who were fluent in Japanese and Chinese conducted the survey for Japanese and Chinese participants, whereas those students with fluency in English administered the survey to English speaking tourists. The survey was conducted during the World Cup period at the major stadiums in Seoul, Suwon, and Incheon. The data collection was also conducted at the departure gates of the major international airport at Incheon. At these venues research assistants approached World Cup attendees and asked them if they would like to complete a short questionnaire on their experiences as a sport tourist. If they agreed they were either provided with the questionnaire to self-complete in a choice of Korean, Japanese, and Chinese, or the field researchers completed the questionnaire via personal interview. Of the questionnaires distributed 277 were fully completed.

The survey instrument was initially written in English and then translated into the three languages. It had four demographic questions, two questions on pattern of game attendance, three general questions on perceptions of how issues of security and safety effected their decision to travel to the event. The security items were measured 
on a five-point Likert scale labelled strongly disagree and strongly agree at the poles and neutral at the mid point, using a set of eight items asking about their experiences of the event. There were also three open-ended questions providing respondents the opportunity to write additional comments about security issues, or safety related suggestions for future events. The sample represented respondents from 18 countries. The majority of these were from Korea (44.4 \%), Japan (20.6\%) and China (11.6\%) as indicated in Table 1. The mean age of respondents was 31 years. Fifty-seven percent were male and 43 percent female. Seventy-three percent of respondents had completed university education.

Insert table 1 here

\section{Results}

An examination of the participation patterns of the respondents revealed that some 46 percent had only attended one game in Korea, with the remaining 54 percent having been to more than one game. Most of the respondents had travelled to watch the World Cup matches and support the Korean team (54\%), followed by supporters for China (8\%), Japan (7\%) and Germany (6\%). The most common group size of these tourists was three people (44\%), then two (22\%) and alone (20\%) with the mean group size 2.6.

Nearly 85 percent of respondents were not worried about issues of security surrounding their attendance at the World Cup. Only 10 percent had considered not coming to the World Cup because of security related concerns and only 1 percent 
expressed an extremely high level of concern. The reasons that respondents gave for not being worried included: 'I do not worry because security was tightened'; 'because I may not watch the world cup again'; and 'I like to watch the team.' While there were only a small number that indicated higher levels of concerns, they travelled to the event despite these apprehensions. Some of the open-ended comments about the reason for this were; 'recommendation by boyfriend; and 'recommendation by husband’. Only 15 percent reported that their families were concerned about their attendance.

Most respondents (76\%) felt either safe or very safe with the security measures taken by the event organisers. Respondents reported that they perceived security measures were most visually apparent at the stadia and the airport, with police presence on transport, and the army at accommodation sites (in descending order of the level of obviousness). In terms of the areas at which respondents felt safest, the respondents felt safest at the stadium and least safe at their accommodation (Table 2).

Insert Table 2 here

Only a small minority of respondents (6\%) thought that the security measures put in place for the event detracted from their level of enjoyment. Conversely, 22 percent enjoyed their sport tourist experience and stated that the heightened and obvious level of security enhanced their time in Korea. This is represented in comments such as, 'if terrorists are not effectively controlled I would not come to 
Korea', and 'I feel the Korean army and police made me very safe'. Some 70 percent were unaffected either way. In terms of group size, it was only the sport tourist respondents who travelled in groups of five or less felt that the security lessened their enjoyment of the event.

Analysis of the data by gender, nationality, and age revealed few significant differences in perceptions of security measures. However, there were two areas in which there was a significant difference. Firstly, Chinese and American tourists were more likely to report that they felt the high level of security was attractive. Secondly, the domestic tourists (Koreans) were the only nationality group that indicated the security detracted from their experience at the World Cup. The Korean respondent comments reflected a feeling that they should not be subjected to the same security measures as foreign tourists. Their remarks included, 'security check for foreign tourist arrivals only', and 'limit to foreign tourist'.

Respondents were provided with the opportunity to write general comments about their perceptions about security for the event and their level of enjoyment of their World Cup experience. Of those who chose to complete this section the most frequent comments were centred on the fact that this was a once in a lifetime experience, so they did not really give security concerns much priority in their decision to attend the event. 'Most people ignore the possibility of these happening and enjoy the sport' (Japanese female, 25 years old, supporter of Japanese team) was one comment which supported the notion of the sport tourists being focussed on the event and not placing much emphasis on terrorism. Comments such as, 'I feel the 
Korean army and police made me very safe’ (Chinese female, 31 years old, supporter of Chinese team), and 'good security' (New Zealand, 28 years old, supporter of Turkey) were common. Other respondents, including males and females from Japan, China, New Zealand, Hong Kong, Canada and Korea, made similar comments. This suggests that these sport tourists felt comfortable with the level of safety provided by the host country. A number of respondents commented that any more security would be invasive, (including 6 males from Korea, 1 male from Japan and 2 Korean females). A male, aged 24 years, from the United States a supporter of the Korean team wrote: 'we are here for watching soccer. So I do not want police to stay here'. A 25 year old Japanese male supporter of the Japanese team commented that: 'more tight security control will be rather harmful’.

There was a question asking if the respondents had any suggestions about security measures for future sport events, given their experience of the 2002 World Cup. Most responses to this question were proposals about increasing the number of police without appearing too militaristic. Other suggestions about the event organisation were related to: increasing the level of communication to spectators about the security and safety measure in place; ensuring that this information was in appropriate languages so that all tourists could access it; educating the people coming to the event on security measures; better (clearer) identification of security personnel; and less control on the cheering materials brought into the games.

The final section of the questionnaire asked respondents to comment on the impact of terrorism on sport events. The responses to this question were wide ranging. The most frequent response was that many people were more anxious and nervous about attending major events because of the perceived threats to safety. This is 
evidenced in the following responses, 'I cannot enjoy sport activities' (Chinese, female aged 30 years supporting the Chinese team), 'it gives sport lovers pain' (Chinese male aged 36 years, supporting the Chinese team) and two Korean 20 year old males, supporting the Korean team, stated; 'it promotes unrest'. The next most frequent response was related to the negative impact of terrorism on sport tourism, as people were less likely to travel to watch the event.

Other comments suggested that sport could be used to combat terrorism, 'world sport events are very useful against terrorism', (Japanese males, aged 31 years, supporting the Korean team) through to opinions that the two should be kept separate, 'sport is sport, do not make bad use of sport as politics', (Korean male, aged 48 years, supporting the Korean team) 'sport and politics are totally different' (Japanese male, 36 years old, supporting the Japanese team) and 'sport and politics should not mix' (Korean male, aged 25 years, whose team allegiance was not identified). Some respondents felt that there was no danger, 'terrorists do not target sport' (Italian males, aged 46 years, supporting the Italian team), and 'most people ignore the possibility of these happening and enjoy the sport' (Australian female, aged 49 years, supporting the Korean team).

\section{Discussion}

The impact of hallmark events such as the World Cup is usually measured on a multitude of indices including economic, tourism/commercial, physical, sociocultural, psychological and political impacts (Ritchie, 1984). This paper has taken a 
rather different perspective and focused not on the impact of the event on the host country but rather on the impact of external threats of terrorism and spectators' perceptions of safety and responses to security measures.

While all FIFA World Cup events impart significant impacts due to the sheer size of the event and its widespread global attention, the 2002 World Cup faced quite a different type of scrutiny coming so soon after a major act of terrorism. The decision of supporters to travel to attend matches and partake in the associated activities took on a completely different dimension in light of the uncertainly about future terrorism targets. The pressure on security was intense during this World Cup for different reasons to previous FIFA World Cups, which had concentrated on anticipating and preventing acts of soccer hooliganism on and off the fields of competition, and in city streets and entertainment venues.

The event organisers were obliged to invest time and financial resources in security measures due to the inherent threat of terrorism. At the same time the organisers also had to ensure that the people travelling to watch and participate in the event were not overwhelmed by the heightened security to the extent that it detracted from their World Cup experience and their experience of Korea.

The findings of this survey conducted with visitors to the World Cup indicate that security was not a major factor in respondents' decisions to attend the 2002 World Cup, despite the events of 9/11. As only those who attended were surveyed, the data do not represent the opinions of people who decided not to travel to the event 
because of security concerns, it could be expected that some of the travellers would have been tentative about their ultimate decision to attend the event. The research found very few people indicated that they were in the latter category. The majority of respondents, dedicated sport tourists, replied that they were going to make the trip regardless of perceived security risk. Even though security was not significant in their decision to travel to the World Cup, once they were in the country a significant proportion was conscious of the safety measures undertaken by the organisers. In most cases the high levels of security were appreciated and did not detract from the attendees' experience of the event. The reported perceptions of the survey respondents were that the World Cup organisers successfully instituted tight security to prevent terrorism incidents and these measures did not detract from sport tourists enjoying the football competition.

The survey results highlight a number of considerations that other sport event organisers might consider in relation to the uncertainly of terrorism threats. It was apparent that for those who did decide to attend the World Cup it was important that they felt safe without the event becoming dominated by oppressive security measures. Increasing the number of police and associated security personnel without appearing too militaristic both eased spectators' anxiety and allowed them the opportunity to enjoy the event. In this respect the organisers could be judged as rising to Zauhar's (2002) challenge of embracing ‘saboteur’ prevention and protecting sport tourists without detracting from their satisfaction and ultimate experience. 
It is also important that visitors are provided with a sufficient level of communication about the risk management measures put in place for the event. This information should be available in different languages and via a range of media; written, visual and verbal. Measures to educate tourists about security measures, and how to adhere to any specific safety requirements, also should be addressed. However, a balance is required to ensure that such measures do not detract from the event experience and compromise the reason that sport tourists choose to travel and attend the event. Therefore even seemingly mundane actions such as controlling cheering materials, for example flags and hooters, brought into the games, should be as unobtrusive as possible, as these items are often fundamental to spectators' experience of the event. The sport spectator endeavours to maximise their experience through engaging in it with all their senses, dressing in team colours, cheering, shouting, clapping and waving flags. To diminish or constrain any of these experiences is, in the case of international football, to compromise the sport tourist's experience.

\section{Conclusion}

These findings regarding the World Cup are particularly relevant to Australia because of the negative effects that 9/11, Bali bombings and the Iraq War have had on tourism in Australia. The resulting problems in tourism have led to government initiatives to rekindle the market, and capitalise on Sydney's successful hosting of the 2000 Olympic Games. In July 2003, the Federal Tourism Minister, Joe Hockey delivered a speech in Japan that was critical of the New South Wales state government for reducing its tourism budget by \$A 3.3million. More importantly, he claimed that the city of Sydney was complacent and without any annual mega events. 
Significantly, in his 10 point plan for re-energising Australia's tourism gateway were suggestions to: develop world class annual events; develop 'purpose travel' in highyield niche markets, for example sport tourism; and promote Sydney as a golf hub in Asia (Scala \& Yamine, 2003).

Sydney will be the focal point of the upcoming 2003 World Cup Rugby and the NSW government has formed a Major Events Board within the Premier’s Department. However, it is Melbourne, the capital of the state of Victoria that is regarded as the nation's event capital. On an annual basis Melbourne stages the Australian Tennis Open, the Australian Formula One Grand Prix and the Melbourne Cup horse racing carnival. In addition, the city is hosting the 2004 World Championships for track cycling and hot air ballooning, the 2006 Commonwealth Games, and has recently been awarded the 2007 FINA World Swimming Championships.

The reliance on an event-driven strategy for tourism revitalisation, in a climate of concern regarding terrorism, means that Australian event organisers need to ensure spectators' safety while ensuring that they are satisfied by their experience. This study has examined the relationship between a sport tourist's intention to travel to a sport event and their perceptions of safety and enjoyment while at the stadium. These are attributes that future mega event organisers will need to be cognisant of in the current Australian climate of uncertainty and fierce competition between cities to achieve the economic and imaging benefits associated with the successful staging of sports events. 


\section{References}

2002 FIFA World Cup, 2002. www.fifa.com/en/display/article,52260.html. 22 August 2003.

Asahi Evening News. 2002. World Cup security must still let fans have fun. global.factiva.com. 24 May 2003.

Atkins, D. 2001. PM links terror to asylum seekers. 7 November. www.news.com.au/common/story_page,. 17 July 2003.

Atkinson, Michael and Young, Kevin. 2002. Terror Games: Media treatment of security issues at the 2002 Winter Olympic Games. Olympika: the International Journal of Olympic Studies 9; 53-78.

Australian Department of Foreign Affairs and Trade, 2003, Advancing the National Interest, http://www.dfat.gov.au/ani/index.html, 23 July 2003.

Colman, Mike. 2001. Sports Brands. Brisbane Courier Mail. 13 October, p. 31.

Council on Foreign Relations. 2003. Terrorism and the Media.

http://www.terrorismanswers.com/terrorism/media.html 14 April 2003. 
De Knop, Paul. 1990. Sport for all and active tourism. World Leisure and Recreation 32; 30-6.

Delpy, Lisa. 1996. Marketing notes: The 1996 Olympic Games. Sport marketing quarterly 5(2), 43-44.

El Salvador War and Football, 2003,

http://www.megastories.com/mitch/map/salvador.htm. 22 August 2003.

Faulkner, Bill and Raybould, Mike. 1995. Monitoring visitor expenditure associated with attendance at sporting events: An experimental assessment of the diary and recall methods. Festival Management and Event Tourism 3; 73-81.

Freedman, Lawrence. (Ed), 2002. Superterrorism., Malden, MA.: Blackwell Publishing.

Funk, Daniel and James, Jeff. 2001. The psychological continuum model: a conceptual framework for understanding an individual's psychological connection to sport. Sport Management Review 4; 119-150.

Ganor, Boaz. 2001. Terrorism: No Prohibition Without Definition.7 October. http://www.ict.org.il/articles/articledet.cfm?articleid=393. 14 April 2003. 
Getz, Don. 1998. Trends, strategies, and issues in sport-event tourism. Sport Marketing Quarterly 7; 8-13.

Gibson, Heather. 1998. Sport tourism: A critical analysis of research. Sport Management Review 1(1); 45-76.

Gibson, Heather. 1999. Sport tourism: The rules of the game. Parks \& Recreation, 34 (6); 36-45.

Gibson, Heather, Attle, Simon and Yiannakis Andrew. 1998. Segmenting the sport tourist market: A lifespan perspective. Journal of Vacation Marketing 4; 52-64.

Gibson, Heather, and Yiannakis, Andrew. 1992. Some correlates of the Sport Lover (Tourist): A life course perspective. Paper presented at the North American Society for the Sociology of Sport Conference. Toledo, Ohio. 4-7 September.

Green, Christine, and Chalip, Laurence. 1998. Sport tourism as the celebration of subculture. Annals of Tourism Research 25; 275-92.

Hall, C. Michael. 1992 Hallmark Events: The Impacts, Management, and Planning of Event Tourism, Belhaven Press: New York.

Hinch, Tom and Higham, James. 2001. Sport Tourism: A Framework for Research. The International Journal of Tourism Research. 3(1); 45-58. 
Hill, Brad and Green, B. Christine. 2000. Repeat attendance as a function of involvement, loyalty and the sportscape across three football codes. Sport Management Review 3; 145-162.

Horne, John. and Manzenreiter, Wolfram. (Eds.) 2002. Japan, Korea and the 2002 World Cup. London: Routledge.

Irwin, Richard, Wang, P. and Sutton, William. 1996. Comparative analysis of diaries and projected spending to assess patron expenditure behavior at short-term sporting events. Festival Management and Event Tourism 4; 29-37.

Kelly, J. 2000. Looking to sports for development dollars. American City \& Country. 115(14); 20.

Manzenreiter, Wolfram and Horne, John. 2002. Global governance in worldsport and the 2002 World Cup Korea/Japan. In Japan, Korea and the 2002 World Cup eds John Horne, J. and Wolfram Manzenreiter. pp 1-27. London: Routledge.

McCormack, Gavan. 2002. Things more important than football? Japan, Korea and the 2002 World Cup. In Japan, Korea and the 2002 World Cup eds John Horne, J. and Wolfram Manzenreiter. pp 29-42. London: Routledge.

Miller, Wayne. 2003. Bomb blast was delayed by 24 hours. Sydney Morning Herald July 5; 5 . 
Nogowa, Haruo, Yamguchi, Y. and Hagi Y. 1996. An empirical research study on Japanese sport tourism in Sport-for-All Events: Case studies of a single-night event and a multiple-night event. Journal of Travel Research 35 (2); 46-54.

Online Asia Times, 2002. Co-hosting hurts Korea's World Cup tourism.

http://www.atimes.com/koreas/koreas.html. 25 June 2002.

Republic of Korea, 2002(a). Dynamism at its best- Korea. Ministry of Finance and Economy.

Republic of Korea, 2002(b). The Korean economy- viewed from overseas. Ministry of Finance and Economy.

Ritchie, JRB. (1984). 'Assessing the impact of hallmark events: conceptual and research issues'. Journal of Travel Research 23(1); 2-11.

Roche, Maurice. 2000. Mega-events and modernity: Olympics and expos in the growth of global culture. London: Routledge.

Scala, Mark and Yamine, Evelyn. 2003. Putting Sydney back on the tourist map. Daily Telegraph 12 July; 17. 
Selth, Andrew. 1988. Against every human law. Canberra: Australian National University Press.

Standeven, Joy and DeKnop, Paul. 1999. Sport Tourism, Human Kinetics:

Champaign, Illinois.

Sunday Age (Melbourne). 2002. The security game. global.factiva.com. 15 December 2002.

Tabata, R.S. 1992. Scuba diving holidays. In Special interest tourism eds. Betty Weiler and C. Michael Hall. pp. 171-84. London, UK: Belhaven Press.

Taylor, Rogan. 2002. World Cup fans: hooligans or tourists. In Proceedings of the Korean Academic Society of Tourism Management International Conference for the Success of the 2002 World Cup., pp. 22-35. Seoul. 18 January.

Terrorism Research Centre. 2003. The Basics of Terrorism: Part two. www.terrorism.com/analysis.shtml. 11 April 2003.

Terrorism Research Centre. 2000. Terrorism threat to the Australian Olympics. www.terrorism.com/analysis-olympics.shtml. 11 April 2003. 
The Washington Post. 2000. Teams try to balance fans’ security, liberties. global.factiva.com. 30 September 2002.

Toohey, Kristine and Veal, Anthony. 2000. The Olympic Games: a social science perspective, Oxon: CABI.

Toohey, Kristine (Ed). 2001. The Official Report of the Games of the XXVII Olympiad, Sydney: SOCOG.

Triadó, Xavier, Aparicio, Pilar and Rimbau, Eva. 1999. Identification of factors of customer satisfaction in municipal sports centres in Barcelona. Some suggestions for satisfaction. Cyber-Journal of Sport Marketing. 3 (4) www.cjsm/v3n4/triado34.htm 18 July 2003.

Warning, Peter, Toohey, Kristine and Ching, Rosie. 2001. Mapping the discipline of the Olympic Games: an author co-citation analysis. In Proceedings of Sports Information in the Third Millennium: $11^{\text {th }}$ IASI World Conference. pp. 339-345. Lausanne. 25-27 April.

United States, Dept. of State. 2001. Patterns of Global Terrorism. Washington: Dept. of State: vi. http://www.history.navy.mil/library/guides/terrorism.htm\#definition. 14 April 2003. 
Van Leeuwen, Linda, Quick, Shayne and Daniel, Kerry. 2002. The Sport Spectator Satisfaction Model:A Conceptual Framework for Understanding the Satisfaction of Spectators. Sport Management Review. 5 (2) 99-128.

Wedermeyer, B. 1999. Sport and terrorism. In The international politics of sport in the $20^{\text {th }}$ century eds. Jim Riodan and Arnd Krüger. pp. 217- 231. New York: Routledge.

Westerbeek, Hans and Shilbury, David. 1999. Increasing the focus on 'place' in the marketing mix for facility dependent sport services. Sport Management Review. 2; 123.

Whitaker, Brian. 2001. The definition of terrorism. The Guardian. 7 May. http://www.guardian.co.uk/elsewhere/journalist/story/0,7792,487098,00.html

Wicks, Bruce. 2002. World Cup fans: hooligans or tourists. In Proceedings of the Korean Academic Society of Tourism Management International Conference for the Success of the 2002 World Cup., pp. 22-35. Seoul. 18 January.

Zauhar, John. 2002. Editorial Comment, Risk management and/or saboteur prevention. Journal of Sport Tourism. 7 (1); 5. 
Table 1: Respondent nationality

\begin{tabular}{|l|r|r|}
\hline \multicolumn{1}{|c|}{ Nationality } & Frequency & \\
\hline Korean & 123 & 44.4 \\
\hline Japanese & 57 & 20.6 \\
\hline Chinese & 32 & 11.6 \\
\hline North \& South American & 19 & 6.9 \\
\hline European & 23 & 8.3 \\
\hline Other Asian & 12 & 4.3 \\
\hline $\begin{array}{l}\text { Australian } \\
\text { \& New Zealand }\end{array}$ & 7 & 2.5 \\
\hline Other & & \\
\hline Total & 4 & 1.4 \\
\hline
\end{tabular}

Table 2: Descriptive Statistics and Pearson's Correlations of Likert Items of Safety at Noted locations

\begin{tabular}{|l|l|l|l|l|l|l|l|}
\hline & Mean & s.d. & 1 & 2 & 3 & 4 & 5 \\
\hline $\begin{array}{l}\text { 1. Airport } \\
\text { security }\end{array}$ & 2.339 & 1.28 & & & & & \\
\hline $\begin{array}{l}\text { 2 Stadium } \\
\text { security }\end{array}$ & 2.142 & 1.22 & -.044 & & & & \\
\hline $\begin{array}{l}\text { 3 Accommo- } \\
\text { dation } \\
\text { security }\end{array}$ & 3.656 & 1.25 & -.114 & $-.212^{* *}$ & & & \\
\hline $\begin{array}{l}\text { 4 Army } \\
\text { 5 Police }\end{array}$ & 3.369 & 1.44 & $-.303^{* *}$ & $-.559^{* *}$ & $-.238^{* *}$ & & \\
\hline $\begin{array}{l}\text { 6 Transport } \\
\text { security }\end{array}$ & 3.568 & 1.28 & $-.442^{* *}$ & $-.265^{* *}$ & $-.361^{* *}$ & .107 & \\
\hline
\end{tabular}

** Correlation is significant at the 0.01 level $1=$ very safe, $5=$ =unsafe

* Correlation is significant at the 0.05 level 